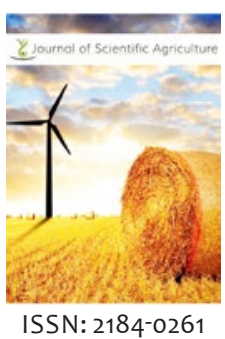

Received: August 7, 2019 Revised: January 29, 2021 Accepted: February 15, 2021 Published: February 28, 2021

Corresponding author: javanomondiwere@yahoo. com

\section{Alternative screening method for drought tolerance in barley genotypes}

\section{Javan Omondi Were'*, Julius Onyango Ochuodho', Nicholas Kipkemboi Rop' and Sanjaya Gyawali²}

'University of Eldoret, School of Agriculture and Biotechnology, Department of Seed, Crop and Horticultural Sciences, P.O. Box, 1125 - 30100, Eldoret, Kenya, ${ }^{2}$ International Centre for Agricultural Research in the Dry Areas (ICARDA), Biodiversity and Integrated Gene Management Program, Morocco

\begin{abstract}
Lack of genetically stable and durable drought tolerant winter and spring barley genotypes is one of the main contributing to low and unpredictable yields in Kenya and other parts of the world despite annual release of new and high yielding varieties. Therefore, the study was set to identify genotypes exhibiting tolerance to drought through physiological and phenotypic approaches. A total of 32 genotypes were planted in split-plot arrangement in completely randomized design replicated thrice. Genotypes were maintained under $20 \%$ and $80 \%$ field capacities. Phenotypic and physiological data were collected, converted to ratios then analyzed on Genstat version 14.1 VSN International Ltd at 5\% level of significance. Significant differences were observed in winter and spring barley in terms of growth, tillering ability, grains formed per spike, 1000 seed weight and MSI $(p<0.05)$. Spring barley expressed higher tolerance to drought than winter barley especially in terms of height, number of grains per spike and seed weight. Water deficiency in cells and tissues might have altered and inhibited physiological and biochemical processes. The phenotypic and physiological methods corresponded and confirmed tolerance to drought in most winter and spring genotypes grown in Kenya.
\end{abstract}

KEYWORDS: Rapid screening, drought, barley, physiological, phenotypic, approaches

\section{INTRODUCTION}

Barley (Hordeum vulgare L.), a member of the grass family, is a major cereal grain ranked fourth was among cereal crops in the world both in terms of quantity produced (136 million tons) and in area under cultivation $\left(566,000 \mathrm{Km}^{2}\right)$ (FAOSTAT, 2009). Important uses include industrial processing as alcoholic and non-alcoholic beverages such as beer, wines, spirits (Ogle, 2006), food for humans with eight essential amino acids, carbohydrates and several minerals (USDA, 2011), feed to livestock and medicinal uses as a component of various health foods to control urinary tract infections, remove toxic substances from kidney and reduce chances of Type II diabetes among others (Ayto, 1990; Reshmi, 2013).

Despite its role in the Kenyan economy, the annual barley yields remain very unpredictable and below $3.0 \mathrm{t} / \mathrm{ha}$ (EABL-UoE, 2016). Additionally, in the past two decades, the annual area under barley in Kenya has been on the decreasing trend (below 20,000 ha) since late 1990s and this has persisted to date (EABL$\mathrm{UoE}, 2013)$. As a result, deficits have been experienced in Kenya since most farmers hardly attain potential yield recorded at $5.5 \mathrm{t} /$ ha (EABL-UoE, 2013). A lot of work have been done on breeding for high yielding varieties with much efforts geared towards screening for resistance to net blotch, drought which occupies about $40 \%$ for the worlds' agricultural land (Demirevska et al., 2008) and aluminium toxicity (EABL-UoE, 2016) but low barley yields is still a major challenge in Kenya.

In Kenya, the actual yields still remain low in barley growing zones despite the existence of numerous breeding lines and new varieties that are released annually for commercial production (EABL-UoE, 2010; EABL-UoE, 2016). This could be due to not only unpredictable and intense drought stresses but also the lack of durable and stable winter and spring adapted barley genotypes the can tolerate drought. This calls for a very rapid and reliable method of screening for drought tolerance among the advanced and genetically stable genotypes that can act as potential germplasm for variety improvement that aims at conferring tolerance to drought.

Lack of rapid and reliable selection approaches for drought tolerance is one of the main bottlenecks for many barley breeders not only in Kenya but also other parts of the world. The precision in such selections is further complicated by the interaction effects of drought and other stress factors such as diseases and 
soil mineral toxicities which collectively can cause yield losses up to 100\% (Bekele et al., 2001; Demirevska et al., 2008; Newton and Goodman, 2005). This compromises the accuracy and reliability of the results. In addition to the interferences by such interactions, most of the methods used to screen for tolerance to drought takes a long time and this could be responsible for the underperformances against drought tolerant barley and other cereals across the globe. This is because by the time a variety is released for commercial production, the environmental conditions could have greatly changed. The study therefore aimed at identifying drought tolerant winter and spring barley genotypes in Kenya through phenotypic and physiological approaches.

\section{MATERIALS AND METHODS}

A total of 32 barley genotypes, 16 adapted to winter growth conditions and 16 adapted to spring growth conditions were sourced from University of Eldoret - East African Breweries Limited Collaborative Barely Research and Variety Improvement program. These included both commercially produced varieties and genetically stable lines.

\section{Phenotypic Approach to Determine Drought Tolerance in Barley}

The barley seeds were sown in plastic containers filled with forest soil with $\mathrm{pH}$ measured at 6.2 (Were and Ochuodho, 2014) to reduce the stress due to acidity under greenhouse conditions. Three seeds of each genotype were planted per pot and at two leaf stage, two watering regimes of approximately $20 \%$ and $80 \%$ of the soil field capacity was adopted and maintained up to physiological maturity. This means that pots maintained at $20 \%$ field capacity (Stressed) received about $1,550 \mathrm{ml}$ (22 $\mathrm{ml}$ per pot per day for 70 days) while those at $80 \%$ field capacity (Unstressed) were supplied with $6,500 \mathrm{ml}$ (93 $\mathrm{ml}$ per pot per day for 70 days) of water through irrigation for the whole experimental period (Pauk et al., 2012).

Due to the obvious genetic differences between the winter and spring genotypes, screening for drought tolerance was done separately using split - plot arrangement in completely randomized design with each genotype replicated thrice. The two water regimes were used as main plots while genotypes were considered to be the sub-plot. Data on agronomic traits including height $(\mathrm{cm})$, number of tillers, number of grains per main spike, and 1000 grain weight $(\mathrm{g})$ were scored at physiological maturity growth stage.

\section{Physiological Approach to Determine Drought Tolerance in Barley}

The physiological approach was selected to act as a confirmatory test to the pot experiment. This was performed at the seed lab in School of Agriculture and Biotechnology, University of Eldoret. Membrane stability index (MSI) was determined by recording the electrical conductivity in $\mathrm{mS}$ (microSiemens) of leaf leachates on EC meter (HI 991301, HANNA Instruments Woonsocket RI USA, ROMANIA) using double distilled water at 40 and $100{ }^{\circ} \mathrm{C}$ (Almeselmani et al., 2011).
The leaf samples for each barley genotype were obtained from the greenhouse experiment at $20 \%$ and $80 \%$ field capacities treatment in three replicates. For each sample, $0.25 \mathrm{~g}$ of leaf samples was cut into discs of uniform size and placed inside test tubes containing $25 \mathrm{ml}$ of double distilled water in two sets. The first set was kept at $40{ }^{\circ} \mathrm{C}$ for 30 minutes while the second set at $100{ }^{\circ} \mathrm{C}$ in water bath for 15 minutes and their respective electrical conductivities $\mathrm{Cl}$ and $\mathrm{C} 2$ were measured by Conductivity meter. Membrane stability index (MSI) was calculated using the formula: $\mathrm{MSI}=1-\mathrm{Cl} / \mathrm{C} 2 \times 100$

The higher the MSI, the more the tolerant a genotype was to drought. For effective comparison on samples subjected to $20 \%$ field capacity (Stressed) with those maintained at $80 \%$ field capacity (Unstressed), tolerance ratios for plant height, number of tillers, number of grains per main spike, 1000 seed weight and MSI were derived for each genotype using the formula: Tolerance ratio $=$ Variable at $20 \%$ field capacity $/$ Variable at $80 \%$ field capacity

Genotypes with ratios equal to or closer to 1.0 were considered tolerant to drought while those closer to or equal to 0.0 were considered to be sensitive to drought stress.

\section{Statistical Data Analysis}

Data on ratios were subjected to analysis of variance on Genstat statistical software release 14.1 VSN International Ltd at 5\% level of significance. The significant mean differences were tested using Duncan Multiple Range Test and results presented in table of ratios and Figures.

\section{RESULTS}

Winter and spring adapted barley genotypes expressed significant differences in their response to drought in terms of tillering ability, growth in terms of height, number of grains per main spike, thousand seed weight and membrane stability index $(p<0.05)$. The additive effects of genotype and field capacities was also significant hence a significant interaction $(p<0.05)$. The differences in ratios in terms of tillering ability, height, number of grains per main spike, thousand seed weight and membrane stability index among the spring and winter adapted barley was observed.

Among the spring barley, FANAKA and HKBL 1805-6 were the most tolerant to drought with reference to tillering ability. This implies that there was no much difference in the number of tillers when these genotypes were subjected to $20 \%$ (stressed) and 80\% (unstressed) growth conditions. However, HKBL 1805-3 and HKBL 1629-14 expressed high sensitivity to drought which significantly affected their tillering ability hence lowest ratio among the spring barley. In terms of height, all the spring adapted barley expressed tolerance to water deficiency and scored above 0.8 , an indication of $80 \%$ similarity between stressed and unstressed. In this regard, HKBL 1805-6 and HKBL 1774-3 were the most tolerant to drought with perfect similarity under stressed and unstressed conditions (Table 1). 
Table 1: Table of ratios on the response of SPRING adapted barley to drought under screenhouse conditions

\begin{tabular}{|c|c|c|c|c|c|c|c|c|c|c|}
\hline \multirow{2}{*}{$\begin{array}{l}\text { GENOTYPE } \\
\text { FANAKA }\end{array}$} & \multicolumn{2}{|c|}{ Number of tillers } & \multicolumn{2}{|c|}{ Plant height } & \multicolumn{2}{|c|}{ Grains per spike } & \multicolumn{2}{|c|}{1000 SWT } & \multicolumn{2}{|c|}{ MSI } \\
\hline & 0.9 & $c d$ & 0.9 & bcde & 0.8 & $d$ & 0.9 & $f$ & 0.9 & $d$ \\
\hline HKBL 1629-14 & 0.5 & $a b$ & 0.8 & $a b c d$ & 0.3 & a & 0.6 & $a b$ & 0.9 & $c d$ \\
\hline HKBL 1629-5 & 0.7 & bcd & 0.8 & $a b$ & 0.2 & $a$ & 0.6 & $a b$ & 0.9 & $\mathrm{~cd}$ \\
\hline HKBL 1663-3 & 0.6 & $b c$ & 0.8 & $a b c$ & 0.6 & $b c$ & 0.9 & ef & 0.8 & $b c$ \\
\hline HKBL 1674-4 & 0.8 & bcd & 0.9 & bcde & 0.5 & b & 0.7 & bcd & 0.9 & bcd \\
\hline HKBL 1719-4 & 0.7 & bcd & 0.9 & bcde & 0.5 & $b c$ & 0.8 & def & 1.0 & $d$ \\
\hline HKBL 1774-3 & 0.7 & bcd & 1.0 & de & 0.6 & $b c$ & 0.6 & $b c$ & 1.0 & $d$ \\
\hline HKBL 1805-3 & 0.3 & a & 0.8 & a & 0.3 & a & 0.6 & $a b$ & 0.6 & a \\
\hline HKBL 1805-6 & 0.9 & d & 1.0 & $\mathrm{e}$ & 0.8 & d & 0.9 & ef & 0.8 & $b c d$ \\
\hline HKBL 1861-1 & 0.8 & bcd & 0.9 & cde & 0.6 & $b c$ & 0.6 & b & 0.9 & $b c d$ \\
\hline HKBL 1862-5 & 0.6 & $b c$ & 0.8 & $a b c$ & 0.6 & $b c$ & 0.5 & a & 0.9 & $b c d$ \\
\hline KARNE & 0.8 & $\mathrm{~cd}$ & 0.9 & cde & 0.6 & $b c$ & 0.9 & ef & 0.9 & $b c d$ \\
\hline MALT I & 0.8 & $\mathrm{~cd}$ & 0.9 & cde & 0.8 & $d$ & 0.9 & $f$ & 0.9 & d \\
\hline NGAO & 0.7 & bcd & 0.9 & bcde & 0.7 & $\mathrm{~cd}$ & 0.9 & ef & 0.8 & b \\
\hline NGUZO & 0.8 & bcd & 0.9 & bcde & 0.7 & $\mathrm{~cd}$ & 0.8 & ef & 0.9 & $b c d$ \\
\hline SABINI & 0.8 & $\mathrm{~cd}$ & 0.9 & bcde & 0.7 & $\mathrm{~cd}$ & 0.8 & cde & 0.9 & $\mathrm{~cd}$ \\
\hline MEAN & 0.7 & & 0.9 & & 0.6 & & 0.7 & & 0.9 & \\
\hline Probability & 0.003 & & 0.007 & & $<0.001$ & & $<0.001$ & & $<0.001$ & \\
\hline S.E & 0.0775 & & 0.0323 & & 0.0517 & & 0.0439 & & 0.0359 & \\
\hline S.E.D & 0.1096 & & 0.0457 & & 0.0732 & & 0.0620 & & 0.0507 & \\
\hline$\% C V$ & 18.5 & & 6.3 & & 15.2 & & 10.3 & & 7.1 & \\
\hline
\end{tabular}

While the growth in terms of height was less affected among the spring barley, yield parameters explained by the number of grains per main spike and thousand seed weight (TSW) were

significantly reduced under drought stress compared to unstressed conditions as reflected by the ratios. For instance, HKBL 1629-14, HKBL 1629-5 and HKBL 1805-3 had significant reduction in the number of grains per spike and this strongly corresponded to the thousand seed weight results. Physiologically (MSI), genotypes such as FANAKA, HKBL 18056, MALT 1, NGAO, NGUZO and SABINI expressed higher tolerance to drought and this was in agreement with majority of the scores for tillering ability, height, number of grains per spike and TSW (Table 1).

The use of phenotypic expression and physiological assessment to determine drought tolerance in spring adapted barley showed strong correspondence to each other. Specifically, at 20\% field capacity, FANAKA and HKBL 1861-1 genotypes recorded MSI of 73 and 59 respectively. However, at $80 \%$ field capacity, higher membrane stability indices were recorded but still, FANAKA had higher MSI than HKBL 1861-1, an indication that FANAKA was better than HKBL 1861-l in terms of tolerance to water deficiency though the ratios for MSI were the same. The phenotypic assessment confirms similar results when these two genotypes were subjected to different water deficiency conditions (Figure 1).

Unlike the spring adapted barley, majority of the winter genotypes were more sensitive to drought with significant differences in terms of tillering ability, plant height, number of grains per main spike, TSW and MSI under the influence of genotypes, field capacity and the interaction between genotype and field capacity $(p<0.05)$. In particular, only GRACE, TITOUAN and SY BATYK and PHILADEPHIA expressed significant tolerance in terms of tillering ability. Additionally, the effect of drought on height was more serious in QUENCH and NFC TIPPLE genotypes. With reference to all variables

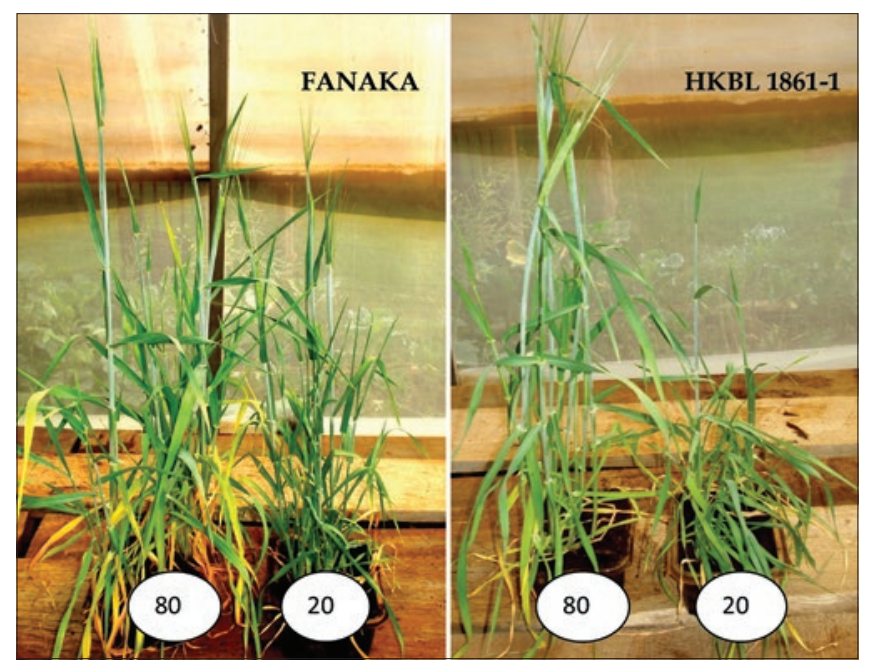

Figure 1: Growth differences of SPRING barley at 80\% (unstressed) and $20 \%$ (stressed) field capacities under greenhouse conditions. FANAKA genotype exhibits more tolerance to water stress compared to HKBL 1861-1

assessed, only GRACE maintained stable tolerance to drought stress (Table 2).

Further, most of the winter barley showed mixed reactions to drought stress and the sensitivity to drought was more expressed compared to the spring barley specifically with reference to yield parameters - the number of grains formed per spike and TSW. For instance, BEATRIX and QUENCH expressed sensitivity across all the variables and this had significant effect on grain development and seed weight. Similarly, just like the spring adapted genotypes, most of the phenotypic observation under drought stress corresponded to that of physiological results of MSI (Table 2).

With reference to phenotypes under the influence of different field capacities, most of the winter adapted genotypes responded 
Table 2: Table of ratios on the response of WINTER adapted barley to drought under screenhouse conditions

\begin{tabular}{|c|c|c|c|c|c|c|c|c|c|c|}
\hline \multirow{2}{*}{$\frac{\text { GENOTYPE }}{\text { ALICIANA }}$} & \multicolumn{2}{|c|}{ Number of tillers } & \multicolumn{2}{|c|}{ Plant height } & \multicolumn{2}{|c|}{ Grains per spike } & \multicolumn{2}{|c|}{1000 SWT } & \multicolumn{2}{|c|}{ MSI } \\
\hline & 0.5 & $c d$ & 0.8 & cde & 0.3 & abcd & 0.7 & bcdef & 0.7 & bcdef \\
\hline ANNABEL & 0.6 & cde & 0.8 & $\mathrm{bcd}$ & 0.4 & de & 0.7 & bcdefg & 0.7 & bcdefg \\
\hline BEATRIX & 0.5 & $\mathrm{bc}$ & 0.6 & $a$ & 0.1 & $a b$ & 0.4 & $\mathrm{a}$ & 0.4 & $a$ \\
\hline COCKTAIL & 0.3 & $a$ & 0.8 & $b c$ & 0.4 & cde & 0.9 & $\mathrm{fg}$ & 0.9 & $\mathrm{fg}$ \\
\hline GRACE & 0.8 & $\mathrm{fg}$ & 0.8 & bcd & 0.7 & $g$ & 0.8 & $\mathrm{fg}$ & 0.8 & $\mathrm{fg}$ \\
\hline MARTHE & 0.6 & cde & 0.8 & bcd & 0.1 & $\mathrm{a}$ & 0.6 & abcd & 0.6 & abcd \\
\hline NFC TIPPLE & 0.5 & bc & 0.5 & $\mathrm{a}$ & 0.4 & cde & 0.8 & cdefg & 0.8 & cdefg \\
\hline PHILLADEPHIA & 0.7 & def & 0.7 & $b$ & 0.3 & bcd & 0.6 & abcde & 0.6 & abcde \\
\hline PUBLICAN & 0.4 & $a b$ & 0.9 & def & 0.2 & $a b c$ & 0.8 & defg & 0.8 & defg \\
\hline QUENCH & 0.5 & $\mathrm{bc}$ & 0.5 & $\mathrm{a}$ & 0.5 & ef & 0.6 & $a b$ & 0.6 & $a b$ \\
\hline SCRABBLE & 0.5 & $\mathrm{~cd}$ & 0.9 & ef & 0.3 & cde & 0.8 & defg & 0.8 & defg \\
\hline SHUFFLE & 0.4 & $a b$ & 0.9 & ef & 0.6 & $\mathrm{fg}$ & 0.8 & $\mathrm{fg}$ & 0.8 & $\mathrm{fg}$ \\
\hline SY 409-228 & 0.6 & cde & 0.6 & $\mathrm{a}$ & 0.4 & cde & 0.9 & $g$ & 0.9 & $g$ \\
\hline SY BATYK & 0.7 & efg & 0.9 & $f$ & 0.2 & abcd & 0.6 & $a b c$ & 0.6 & $a b c$ \\
\hline TITOUAN & 0.8 & $g$ & 0.9 & ef & 0.4 & cde & 0.7 & bcdefg & 0.7 & bcdefg \\
\hline XANADU & 0.6 & cde & 0.8 & bc & 0.4 & cde & 0.8 & efg & 0.8 & efg \\
\hline MEAN & 0.6 & & 0.8 & & 0.3 & & 0.7 & & 0.7 & \\
\hline Probability & $<0.001$ & & $<0.001$ & & $<0.001$ & & $<0.001$ & & $<0.001$ & \\
\hline S.E & 0.0465 & & 0.0305 & & 0.0481 & & 0.0669 & & 0.0250 & \\
\hline S.E.D & 0.0657 & & 0.0432 & & 0.0680 & & 0.0946 & & 0.0354 & \\
\hline$\% C V$ & 14.4 & & 7.0 & & 24.4 & & 15.9 & & 5.5 & \\
\hline
\end{tabular}

in a similar trend just like the spring genotypes. For instance, more tolerance characteristics were phenotypically expressed more in ALICIANA than TITOUAN which was more sensitive to water stress. Further, among the drought sensitive winter genotypes like TITOUAN, significant reduction on height and delayed heading and forced maturity was observed at $20 \% \mathrm{FC}$. The tolerant genotypes including ALICIANA, ANNABEL, GRACE and COCKTAIL did not record significant differences in their MSI in comparison to a number of growth parameters assessed (Figure 2).

\section{DISCUSSION}

Diverse responses to drought among the winter and spring barley grown in Kenya confirms that these genotypes were different from each other and that the degree of tolerance differed from one genotype to the other. When subjected to water deficiency, low tillering ability, stunted growth, low number of grains per main spike and low thousand seed weight was common among the winter and spring barley and it could mean that inadequate supply of water interfered with a number of physiological processes such as translocation and partitioning of photosynthates needed for proper growth and development (Ashoub et al., 2015; Varga et al., 2014).

The higher sensitivity of winter genotypes compared to spring genotypes could further indicate that under drought stress, the quantum yield of light reaction, water-use-efficiency, photosynthetic rates and leaf osmotic potential (Siosemardeh et al., 2010)are significantly reduced hence leading to the higher sensitivity to drought (Ashoub et al., 2015) which is finally expressed by the integrity of the cell wall membrane as confirmed by the membrane stability index.

Among the drought tolerant genotypes such as FANAKA and GRACE, it is possible that a number of biochemical processes were least affected compared to sensitive genotypes such as HKBL 1805-3 and BEATRIX. This is because in most plants,
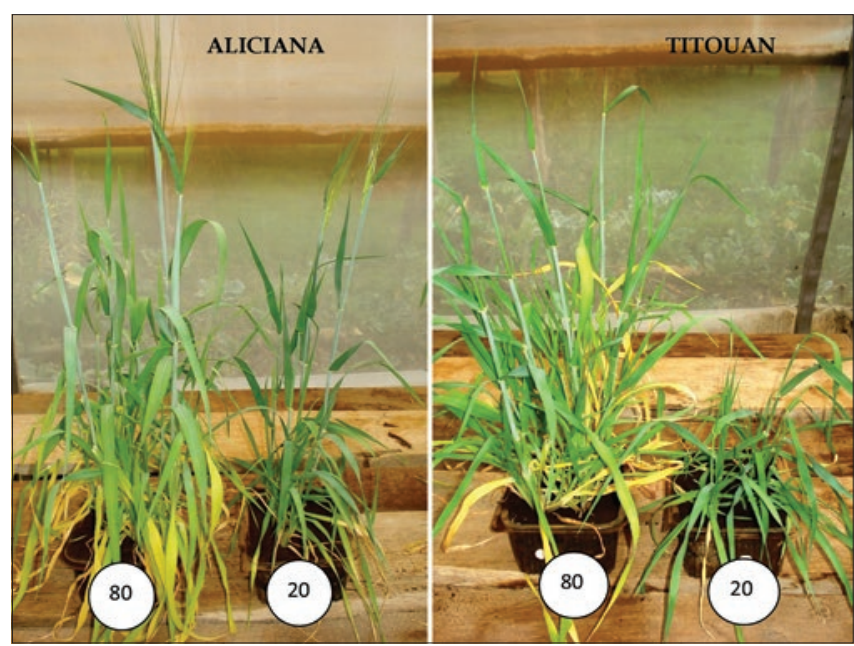

Figure 2: Growth of WINTER barley at $80 \%$ (unstressed) and $20 \%$ (stressed) field capacities under greenhouse conditions. ALICIANA genotype exhibits more tolerance to drought compared to TITOUAN

other than interference with physiological processes (Wang et al., 2016), water deficiency in plant cells and tissues inhibits and/or alters vital biochemical processes such as hormonal balance, stress signal transduction pathways and gene expression (Ashoub et al., 2015). For the drought tolerant winter and spring barley genotypes, the variation in the level of tolerance could have been influenced by a number of factors including the quantity of proline whose production depends on calcium and ABA levels. This is in agreement with the previous findings that drought stress, proline accumulation is the first response to water-deficit stress (Siosemardeh et al., 2010) and once produced, the water uptake from the dry soil is greatly enhanced. When produced, proline acts as signaling molecule to moderate important mitochondrial functions which are needed for drought tolerance such as cell proliferation as well as triggering of specific gene expression such as those needed for ABA synthesis. However, the quantity of proline produced depends 
on the level of available calcium and ABA (Xie et al., 2011). This could also mean that different genotypes signaled the expression of different genes for the production of varying levels of ABA. However, the winter genotypes could have produced low levels of this hormone thus low proline concentration in cells and tissues (Nascente et al., 2016) which resulted to higher sensitivity to drought compared to spring barley.

\section{CONCLUSIONS AND RECOMMENDATION}

Majority of the spring barley including FANAKA, NGUZO, NGAO, MALT 1, KARNE and HKBL 1805-6 were tolerant to drought stress across all parameters while for the winter genotypes, only GRACE was tolerant across all parameters. In addition, tillering ability, height and 1000 seed weight were the most affected variables in barley under drought stress in both winter and spring genotypes. Lastly, the greenhouse water stress experiment and MSI gave corresponding results on tolerance to drought by barley and this provides a cheaper and faster technique of screening barley for their response to water stress. The study recommends genetic confirmation on the observed physiological and phenotypic responses to drought by barley.

\section{ACKNOWLEDGEMENTS}

Authors are grateful to Regional Universities Forum for Capacity Building in Agriculture (RUFORUM) and University of Eldoret - East African Breweries Limited Collaborative Barley Research on Crop Improvement for availing the funds which made these findings possible.

\section{REFERENCES}

Almeselmani, M., Abdullah, F., Hareri, F., Naaesan, M., Ammar, M. A., ZuherKanbar, O., \& Saud, A. A. (2011). Effect of drought on different physiological characters and yield component in different varieties of Syrian durum wheat. Journal of Agricultural Science, 3(3): 127-133. https://doi.org/10.5539/jas.v3n3p127

Ashoub, A., Jedmowski, C., Momtaz, O., \& Brüggemann, W. (2015). Impact of drought, heat, and their combination on chlorophyll fluorescence and yield of wild barley (Hordeum spontaneum), Journal of Botany, 2015, 120868. https://doi.org/10.1155/2015/120868

Ayto. J. (1990). The glutton's glossary: A dictionary of food and drink terms (pp. 16-17). London: Routledge.
Bekele, H., Shambel, K., \& Abashamo, L. (2001). Barley yield loss due to net blotch and leaf rust in Bale highlands. Pest Management Journal of Ethiopia, 5, 45-53.

Demirevska, K., Simova-Stoilova, L., Vassileva, V., Vaseva, I., Grigorova, B., \& Feller, U. (2008). Drought induced leaf protein alterations in sensitive and tolerant wheat varieties. General and Applied Plant Physiology, 34(1-2): 79-102. https://doi.org/10.7892/boris.110728

EABL-UoE. (2010) Collaborative barley research programme: Breeding, Agronomy and Product Assessment Trials, Kenya.

EABL-UoE. (2013) Collaborative barley research programme: Breeding, Agronomy and Product Assessment Trials, Kenya.

EABL-UoE. (2016) Collaborative barley research programme: Breeding, Agronomy and Product Assessment Trials, Kenya.

FAOSTAT. (2009) Food and Agriculture Organization of the United Nations Archived from the original on 8 May 2009. Retrieved 2009-05-18.

Nascente, A. S., Mauad, M., Crusciol, C. A. C., Filho, H. G., \& Lima, G. P. P. (2016). Effects of silicon and drought stress on biochemical characteristics of leaves of upland rice cultivars. Revista Ciência Agronômica, 47(3), 532-539. https://doi.org/10.5935/18066690.20160064

Newton, A. C., \& Goodman, B. A. (2005). Effects of drought stress and its sudden relief on free radical processes in barley. Journal of the Science of Food and Agriculture, 85, 47-53. https://doi.org/10.1002/jsfa.1938

Ogle, M. (2006). Ambitious brew : The story of American beer. Orlando: Harcourt. pp. 70-72.

Pauk, J., Lantos, C., Mihály, R., Flamm, C., Livaja, M., Cseuz, L., Schmolke, M. \& Ruthner, S. (2012). Greenhouse test for drought tolerance of the CORNET wheat variety set. Lehr- und Forschungszentrum für Landwirtschaft Raumberg-Gumpenstein, Tagung der Vereinigung der Pflanzenzüchter und Saatgutkaufleute Österreichs 2011.

Reshmi, A.R. (2013). The Times of India: Food - Barley Water the Best Beverage.

Siosemardeh, A., Mafakheri, A., Bahramnejad, B., Struik, P. C., \& Sohrabi Y. (2010). Effect of drought stress on yield, proline and chlorophyll contents in three chickpea cultivars. Australian Journal of Crop Science, 4(8), 580-585.

USDA. (2011). United States Department of Agriculture: Agriculture research Service, National Agricultural Research Library, Nutrient Data Laboratory, Nutrient Database, Barley grain.

Varga, B., Vida, G., Varga-Laszlo, E., Bencze, S., \& Veisz, O. (2014). effect of simulating drought in various phenop hases on the water use effciency of winter wheat. Journal of Agronomy and Crop Science, 201, 1-9. https://doi.org/10.1111/jac. 12087

Wang, L., Daryanto, S., \& Jacinthe, P. (2016). Global synthesis of drought effects on maize and wheat production. PLoS One, 11(5), e0156362. https://doi.org/10.1371/journal.pone.0156362

Were, J. O., Ochuodho, J. O. (2014). Sensitivity of barley (Hordeum vulgare) to phosphate fertilizer formulations under acidic soils in Kenya. International Journal of Research Studies in Biosciences, 2(6), 50-59.

Xie, X., Anjum, S. A., Wang, L., Saleem M. F., Man, C., \& Lei, W. (2011). Morphological, physiological and biochemical responses of plants to drought stress. African Journal of Agricultural Research, 6(9), 2026-2032. https://doi.org/10.5897/AJAR10.027 